\title{
Performance analysis of using mine water from an abandoned coal mine for heating of buildings using an open loop based single shaft GSHP system
}

\author{
Amin Al-Habaibeh ${ }^{\mathrm{a} *}$, Anup P Athresh ${ }^{\mathrm{a}}$, and Keith Parker ${ }^{\mathrm{b}}$ \\ ${ }^{a}$ Innovative and Sustainnable Built Environment Technologies Research Group (iSBET) \\ Nottingham Trent University, NG1 4BU, UK \\ ${ }^{b}$ Alkane Energy Plc, Edwinstowe House, Edwinstowe, Nottingham, NG21 9PR, UK
}

\begin{abstract}
The application of ground source heat pumps (GSHP) for heating and cooling of buildings is currently increasing in popularity in the UK and globally. Traditional GSHP systems use the naturally available geothermal gradient of earth for heating and cooling purposes using open loop or closed loop systems. In this paper, the use of mine water from a flooded coal mine for heating of buildings is presented using a GSHP system with an open loop configuration. The novelty of this approach is that a single shaft is used to extract the warm water and inject the cooler water back into the same shaft, thereby minimising the area needed, initial capital costs in constructing a doublet system and also potentially overcome the time consuming process to address related environmental agencies regulation regarding the discharging of the mine water. The relatively stable temperature low enthalpy of mine water contained in the abandoned and flooded coal mines are ideal to be used for both heating and cooling of buildings when used in conjunction with heat pumps. The GSHP is considered to be an effective means of reducing the carbon emission as it gives more output in the form of thermal energy in comparison to the electrical energy it consumes as input. This research work reports on the performance of the system over the winter season and its long term potential in converting the mine water from an environmental liability to a sustainable energy resource and offers a means to regenerate the former coal mining areas.
\end{abstract}

Keyword: GSHP; Sustainability; Community Engagement; District heating; Open loop;Mine water; Low Carbon Technology.

\section{Introduction}

* Corresponding author. Tel.: +44 (0) 1158482564.

E-mail address: Amin.Al-Habaibeh@ntu.ac.uk 
The existence of flooded coal mines in many of the industrialised nations is a legacy left behind by the industrial revolution, that occurred on the back of coal mining over the past 200 years. The UK is one of the best examples to see the legacy of the abandoned and flooded coal mines. The coal mining played a pivotal role in UK becoming one of the leading economies in the world on the back of the industrial revolution. Communities in towns and villages surrounding the mines flourished and became prosperous providing employment to thousands of people. This trend later spread to the other countries in Europe.

When the mines were in operation, deep mining of coal involved going further below the water table to extract the coal, this involved continuous pumping of water from the lower geological regions containing the coal seams, this was done to keep the underground seams dry, so that miners could work safely [1]. The pumps were placed at strategic locations within and around the mine complex and dewatering caused a disruption to natural hydrogeological conditions [2]. The pumped water was discharged into the water bodies after removing the suspended particles, iron and other effluents, most often the dewatering operation of an active mine had a big impact on the subsurface hydrogeology [1]. The majority of the coal mines in the UK and other industrialised nations of western Europe were closed down at the end of $20^{\text {th }}$ century due to economic and political reasons $[3,4,5]$. The closure of the collieries led to the termination of pumping as well. Ending of dewatering leads to a gradual recovery of the water level to its initial levels and subsequently filling up the created void spaces due to the extraction of coal with water, leading to dissolution of efflorescent salts that develop in the drained and ventilated areas due to the pyrite oxidation. This causes deterioration in the quality of water in the abandoned workings after the closure of the colliery [6-10]. The quality of the mine water improves but takes a long time which can range from couple of years to couple of decades [7,11-13]. The raising water levels pose a threat to the ground and surface water resources and endanger the local ecology $[14,10]$. There have been instances where surface discharge has occurred and has contaminated the rivers [15], fresh water aquifers [16] and marine environments [17]. In order to prevent mine water from coming in contact with the clean water bodies, the water in most cases is still being pumped even after the closure of mines. In UK, for example, there are 64 sites where the water is being actively pumped [18].

Considerable theoretical and academic studies have been carried out to estimate the thermal energy potential of mine water in flooded coal mines [20-26]. The mining operations created a vast network of shafts, tunnels and workings underground and since their abandonment, they are now filled with water. The temperature of the water is often reaches several degrees centigrade above the annual average air temperature. Normally, the temperature of the ground at a depth of about $100 \mathrm{~m}$ in the UK is circa 13 to $14{ }^{\circ} \mathrm{C}[27]$.

In spite of the obvious economic and environmental benefits, only 28 such schemes have been documented and only $57 \%$ of them were coal mine based [28]. A detailed description of the operational concepts of heat pumps, types and configurations has been presented in references [29] and [30]. The recent advances in heat pump technology have been described reference [31]. The theoretical concepts of using the mine water for heating and cooling applications have been described in several references, see for example $[3,19,27,33,34$,$] . Moreover, an educational lab-based simulator to demonstrate mine water$ heating has been described by the authors [35]. A review and details of the existing and proposed mine water based heating and cooling installations throughout the world has been described by [21] and [24]. A comparison of mine water heating and cooling systems with other technologies along with existing and potential sites in North America has been discussed, and the results show a promising potential [20]. An analysis of important parameters impacting the commercial feasibility of a GSHP in North America has been described in [36]. A mine water based heating scheme operating since 1989 at Nova Scotia in Canada with successful results has been presented in literature [37]. Reference [38] describes a large scale mine water heating scheme in Spain, where heating and cooling is being provided to a university building 
and a hospital, it also describes the possibility of using the discharged water for domestic and industrial applications thereby offering solutions to the mine water discharge problems as well. A comprehensive list of the existing mine water based energy systems has been described in [39]. In the UK, the performance of a mine water based heating system implemented in a housing estate in Scotland has been described [40], in this region an estimated potential of about $12 \mathrm{MW}$ of heat can be harnessed from the Midland Valley of Scotland [41]. The UK's Coal Authority operates a number of pumping stations at various locations throughout UK, pumping large volumes of water from the abandoned coal mines and an estimated $55 \mathrm{MW}$ of heat can be extracted from those discharged water [41,42]. References [43-45] presents an example of how a discharged mine water is suitably being harnessed at the Caphouse Colliery in the UK. A pilot district mine water heating and cooling scheme has been successfully implemented in the Dutch town of Heerlen and the details of this scheme has been described in [46]. Following the success of the pilot scheme, the scheme was upgraded to a full scale sustainable energy system [47]. The scheme at Heerlen has been very fruitful as it shows how a former mining town facing a social and economic crisis following the closure of the mines has successfully managed to transform itself using the mine water heating and cooling scheme to a sustainable energy hub attracting both public and private investments. Heerlen project has shown the way forward to other mining towns around the world still struggling with energy poverty and mine closures, with this community engagement. Other related applications of GSHP in literature also include the use of spiral loop ground heat exchanger (GHE) for a solar-assisted ground source heat pump with support from artificial neural network (ANN) and adaptive neuro-fuzzy inference system (ANFIS) for modelling [48]. The results show that the ANFIS is more successful than that of ANN in forecasting performance of the solar ground source heat pump system. In $[49,50]$ GSHP has been used to investigate snow melting on pavements experimentally and using simulation. Cost vs benefits has been found to be essential to consider such applications. Other applications of GSHP has included the use of spiral type heat exchanger as a standalone greenhouse heating system [51].

The application GSHP for mine water and optimising the performance of the system through a reliable system design requires the availability of high quality data. The concept of using mine water from an abandoned coal mine using a single shaft system, see Figure 1, to extract and inject the water has been previously outlined by the authors [52 - 54]. This paper describes the detailed performance of the system, at Alkane Energy site in Markham, over the winter season when it is utilised for heating the buildings.

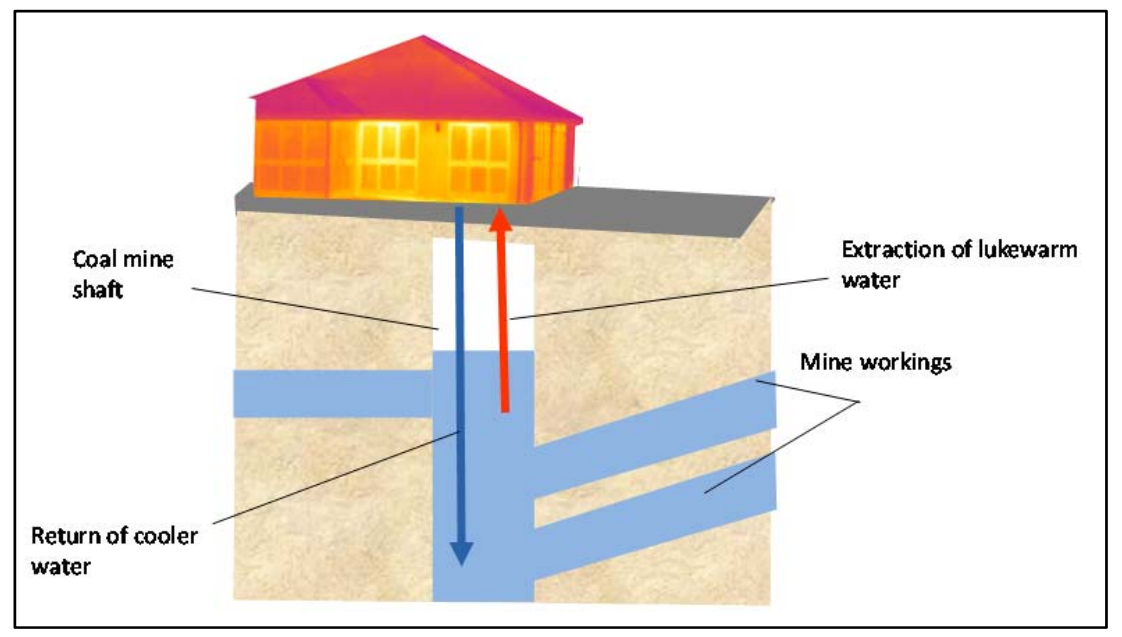

Figure 1: A schematic diagram of a single shaft coal mine GSHP system 


\section{Methodology and Site Location}

This paper aims to investigate the practicality and performance of extracting energy from flooded caol mines using a single mine shaft to extract the relatively warm water and return the cooler mine water back into the same shaft. For that reason Markham coal mine has been selected. Markham coal mine was one of the main collieries in UK and operated from 1905 until its closure in 1993. The underground coal seams were accessed through four shafts present in the colliery complex. After the closure of the mine three of the four shafts were filled, the No. 3 shaft being left open to vent mine gas. This shaft was subsequently utilised by Alkane Energy to extract Coal Mine Methane (CMM) for the purpose of electricity generation. In 2006 the rising mine water caused the methane flow to cease. Alkane Energy converted this site as their control centre and a maintenance depot, from where they could control all their operations across the various sites remotely. The water from the Markham Colliery is now being used to heat the site buildings of the Alkane Energy at Markham through a GSHP. The study methodology is based on practically heating two buildings over the winter months to investigate a wide range of variables and parameters. COP values, water temperature stability and energy extracted were among the parameters monitored and assessed.

\section{GSHP System Description}

A schematic diagram of the mine water heating system in consideration is as shown in the Figure 2 . The detailed description of the system has be given in [52]. The GSHP system consist of a single $20 \mathrm{kWh}$ commercial Danfoss heat pump, counter flow shell and tube type heat exchanger, a 300 litres buffer tank, mesh filter and pipes connecting all the different units. The borehole pump is installed in the mine shaft at a depth of $170 \mathrm{~m}$ below ground level. The return hose of the borehole is at a depth of $150 \mathrm{~m}$ below ground level. As a safety mechanism the methane in the mine shaft is monitored and would shut down the system if the methane level crosses a pre-set level. 


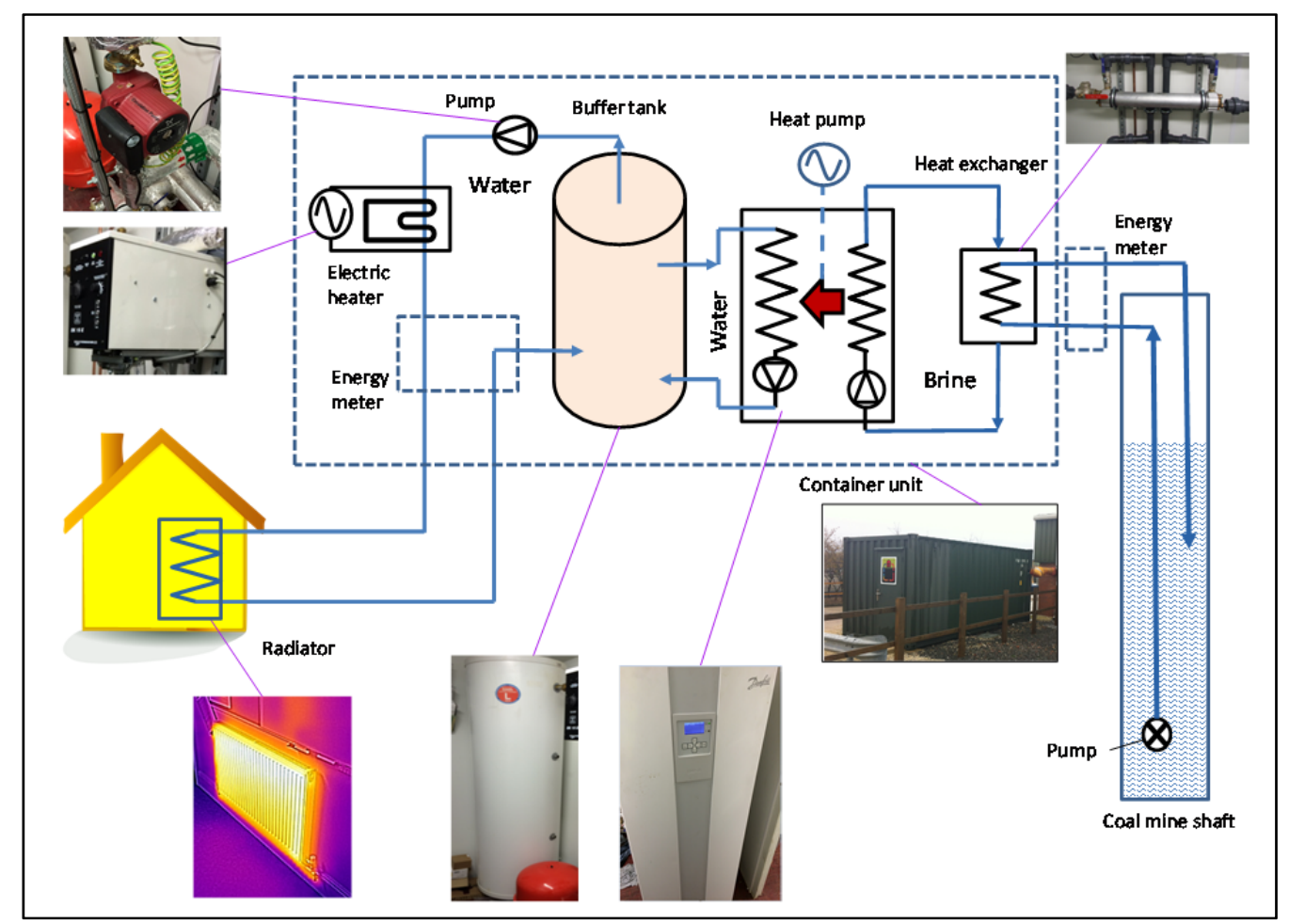

Figure 2: A simplified shematic system of the single shaft GSHP system at Markham, UK.

\section{Instrumentation and Monitoring of the system.}

The main parameters which need to be monitored are energy consumption and heat transfer rates between the mine water and the brine, see Figure 2, and these are determined by measuring the instantaneous fluid flow rate and both out and return temperatures. Energy meters are installed to measure the electricity consumption of the heat pump and mine water pump. Kamstraup heat meters are used to monitor both the mine water and the heat pump output parameters. The heat meter measures the flow rate in $1 / \mathrm{h}, \Delta \mathrm{T}$ of the water in ${ }^{0} \mathrm{C}$, instantaneous energy in $\mathrm{kW}$ and cumulative energy in $\mathrm{MWh}$. The Kampstraump heat meter consists of an integrated flow and temperature sensors and an integrator to calculate the energy based on the flow and temperature values. The entire monitoring system is connected to the internet for remote data capture and analysis. Figure 3 presents some of the main parts of the instrumentation of the system. 


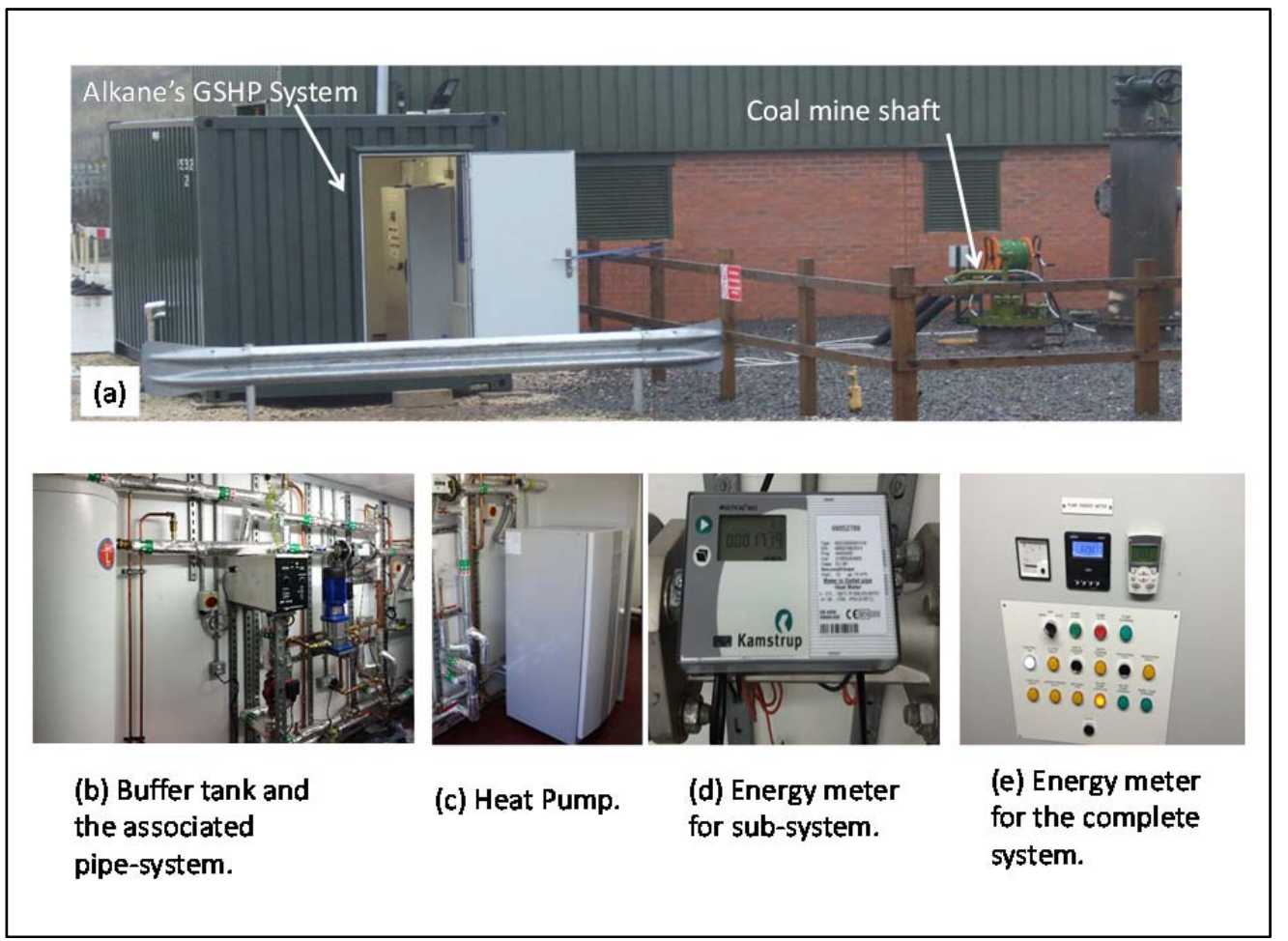

Figure 3: Alkane's GSHP system (a), buffer tank and the associated pipe-system (b), heat pump (c), the energy meter for the coal mine water (d), the energy meter for the complete system (e).

\section{Main Performance Indicators}

When a heat pump is used, it requires energy to drive thecompressor, and the efficiency of operation of the heat pump must be taken into consideration. The efficiency of a heat pump is referred to as its coefficient of performance (COP), it is expressed as the ratio of the heat energy delivered to the electrical energy used to drive the heat pumps. The COP delivered by a given heat pump will depend on the relative input and output temperatures [55]. In normal operation COP's vary in the range of 3-6 [56]. The thermal energy output and electricity consumed by the heat pump mainly depends upon the heat transfer between the mine water and brine, brine and evaporator of the heat pump and between the condenser of the heat pump and the building's heating fluid. Figure 4 shows the difference in temperature between the extraction and return line of the mine water taken through using infrared thermography.

Energy that can be extracted from the mine water can be calculated using equation 1:

$Q_{m w}=m_{m w} \cdot C_{p} \cdot \Delta T \quad k J$

Where:

$Q_{m w}$ is the thermal energy of mine water in $k J, m_{m w}$ is mass of mine water in $\mathrm{kg}, C_{p}$ is the specific heat of water $(4.18 \mathrm{~kJ} / \mathrm{kg} . \mathrm{K})$ and $\Delta T$ is the difference in temperature in Kelvin. 
Efficiency or COP of the heat pump is calculated using equation 2:

$\mathrm{COP}_{\text {Heatpump }}=\frac{Q_{H P}}{W_{\text {HP electrical }}}$

Where

$W_{H P \text { electrical }}$ is the electrical power consumption of heat pump in $\mathrm{kJ}$ and

$Q_{H P}$ is the thermal energy output produced by the heat pump in kJ, expressed as:

$Q_{H P}=m_{H P} \cdot C_{p} \cdot \Delta T \quad k J$

Given that $m_{H P}$ is mass of water circulated in $\mathrm{kg}, C_{p}$ is the specific heat of water $(4.18 \mathrm{~kJ} / \mathrm{kg} . \mathrm{K})$ and $\Delta T$ is the difference in temperature in Kelvin.

Efficiency or COP of the system includes the energy consumed by the heat pump, mine water pump and the circulation pump and it is calculated using equation 3.

$$
\begin{aligned}
& C O P_{\text {system }}=\frac{\text { Thermal Energy produced by system in } k J}{\text { Electrical Energy consumed by system in } k J} \\
& \mathrm{COP}_{\text {system }}=\frac{Q_{H P}}{W_{H P \text { electrical }}+W_{C P} \text { electrical }+W_{M P \text { electrical }}}
\end{aligned}
$$

Where, $\mathrm{W}_{\mathrm{CP} \text { electrical }}$ is the energy consumed by the circulation pump in $\mathrm{kJ}$ and $\mathrm{W}_{\mathrm{MP} \text { electrical }}$ is the energy consumed by the mine water pump in $\mathrm{kJ}$ 


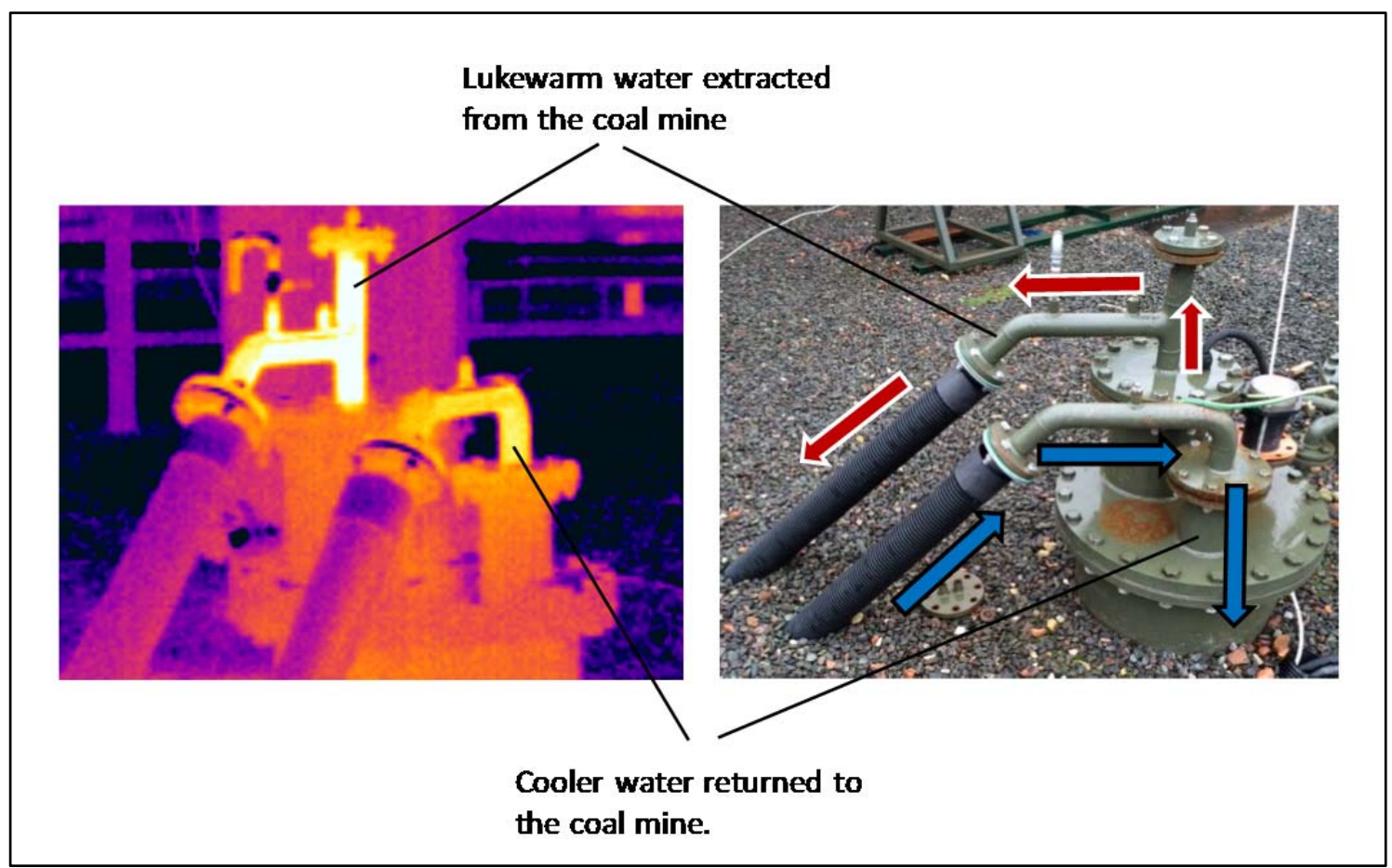

Figure 4: Infrared image of the extraction and return lines (left) and the corresponding visual image (right)

COP of the whole system is the ratio between the energy produced by the heat pump and energy consumed by the system and includes the electricity consumed by the heat pump, mine pump and circulation pumps, see Figure 2. The compressor is the main component in the heat pump that consumes most of the electricity and small amount of electricity is also consumed by circulation pumps to circulate the fluid within the heat pump. The electricity consumption of the heat pump will depend on its design and the efficiency which is based on the input and output level of temperatures of the fluids entering and leaving the heat pump. The other important parameters that impact the overall efficiency are the depth of water in the coal mine (if the water level in the mine is deep then significant amount of energy will be consumed to pump the water to ground level) and the distance through which the hot water has to be transported from the heat pump to the recipient building. 

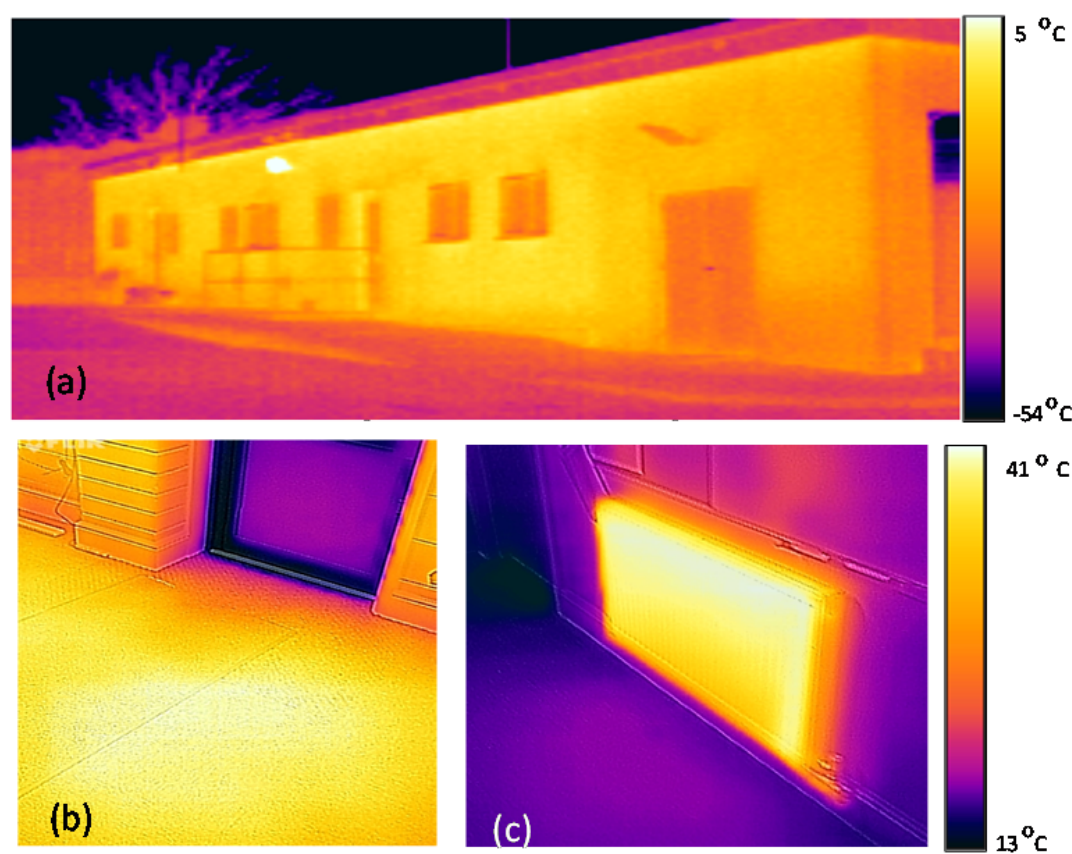

Figure 5: Infrared image of the heated building (a), under floor heating (b) and normalized radiator heating (c).

\section{Results and Discussion}

The performance of the GSHP system operations over the winter period is presented in this paper. Figure 5 presents the infrared thermography images of one of the heated buildings and under floor heating and the normal radiator. During the period of winter testing, the average efficiency (COP) of the heat pump is found to be 3.59 and the overall efficiency of the system is 1.59 . The efficiency is affected by a number of dynamic factors including outside ambient temperature, inside room temperature, heat pump outlet hot water temperature, temperature of the mine water being extracted. The power consumed by the borehole pump has a big impact on the overall system efficiency, if the heat pump efficiency is considered constant.

Figure 6 presents the daily fluctuation of the thermal output from the heat pump, it varies between 276 $\mathrm{kWh}$ to $30 \mathrm{kWh}$. Figure 7 shows the fluctuation in the volume of water that is pumped daily, when more heat is needed, more water will be pumped to extract the required energy. Figure 8 shows the electric consumption of the heat pump and the mine water pump. Figures 9 and10 show that it is possible to get a good and a stable COP of circa 3.5 for most of the time from a GSHP, when mine water is used. The COP values of the GSHP tends to be on a higher side as the heat demand increases and the GSHP's are run for a longer durations at each operational cycle. 


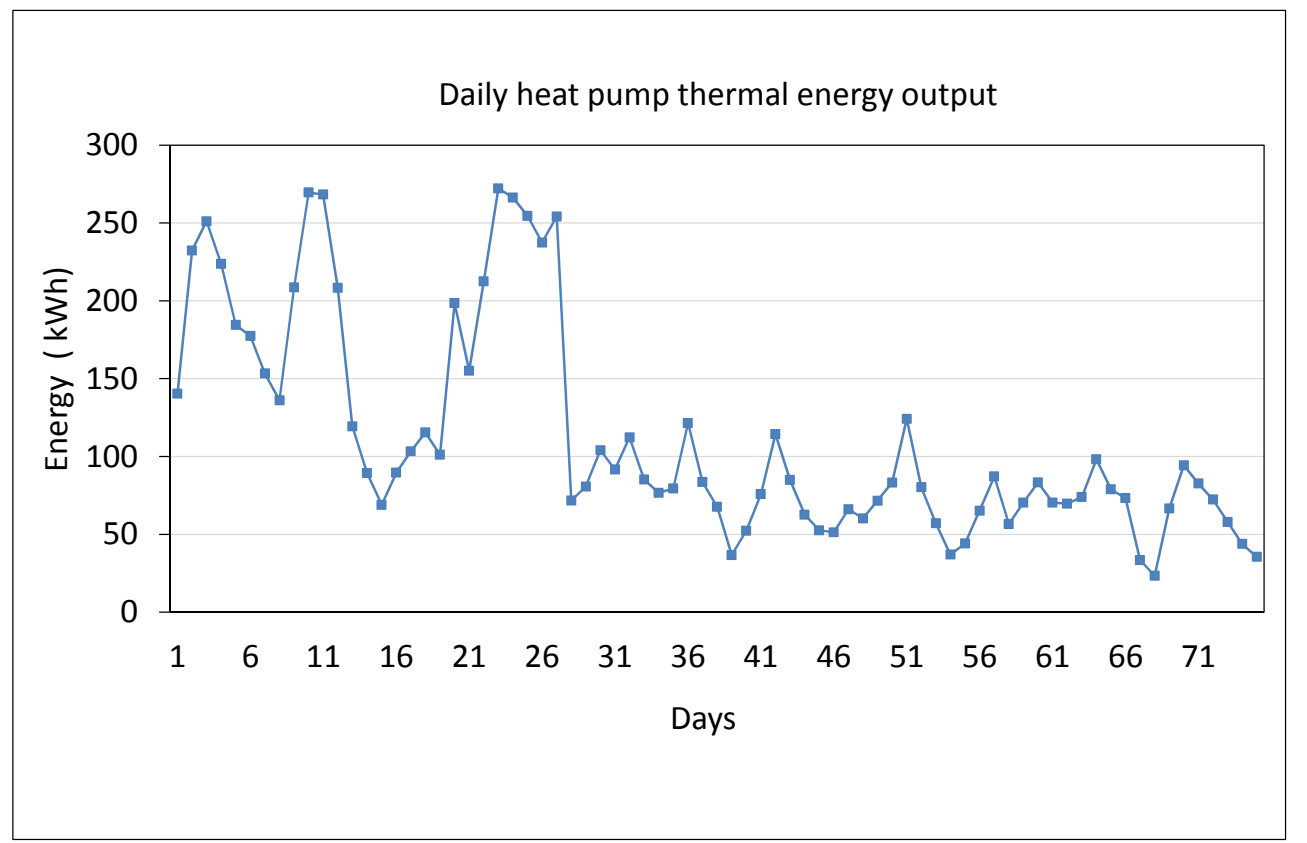

Figure 6: The daily thermal energy output of the heat pump during the 71 days of winter operation.

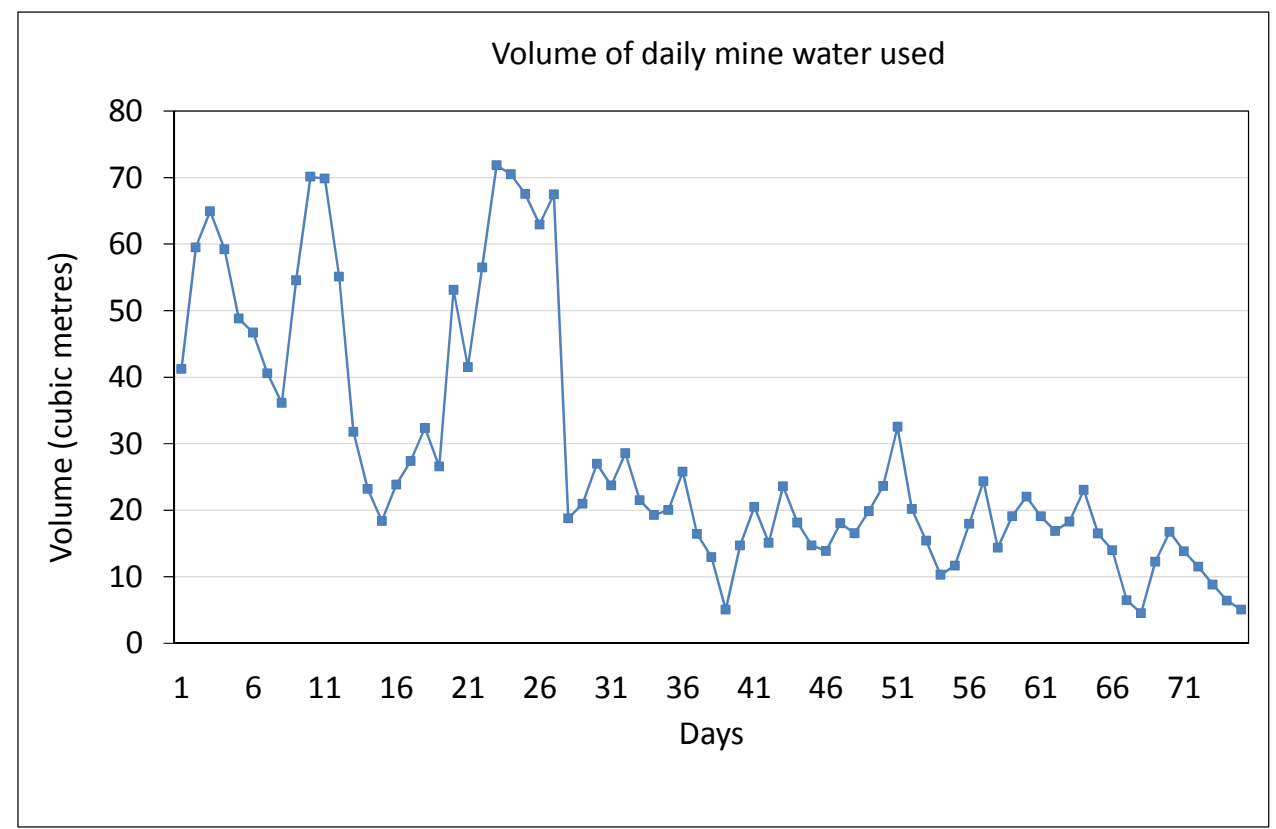

Figure 7: The daily volume of mine water used for heat generation. 


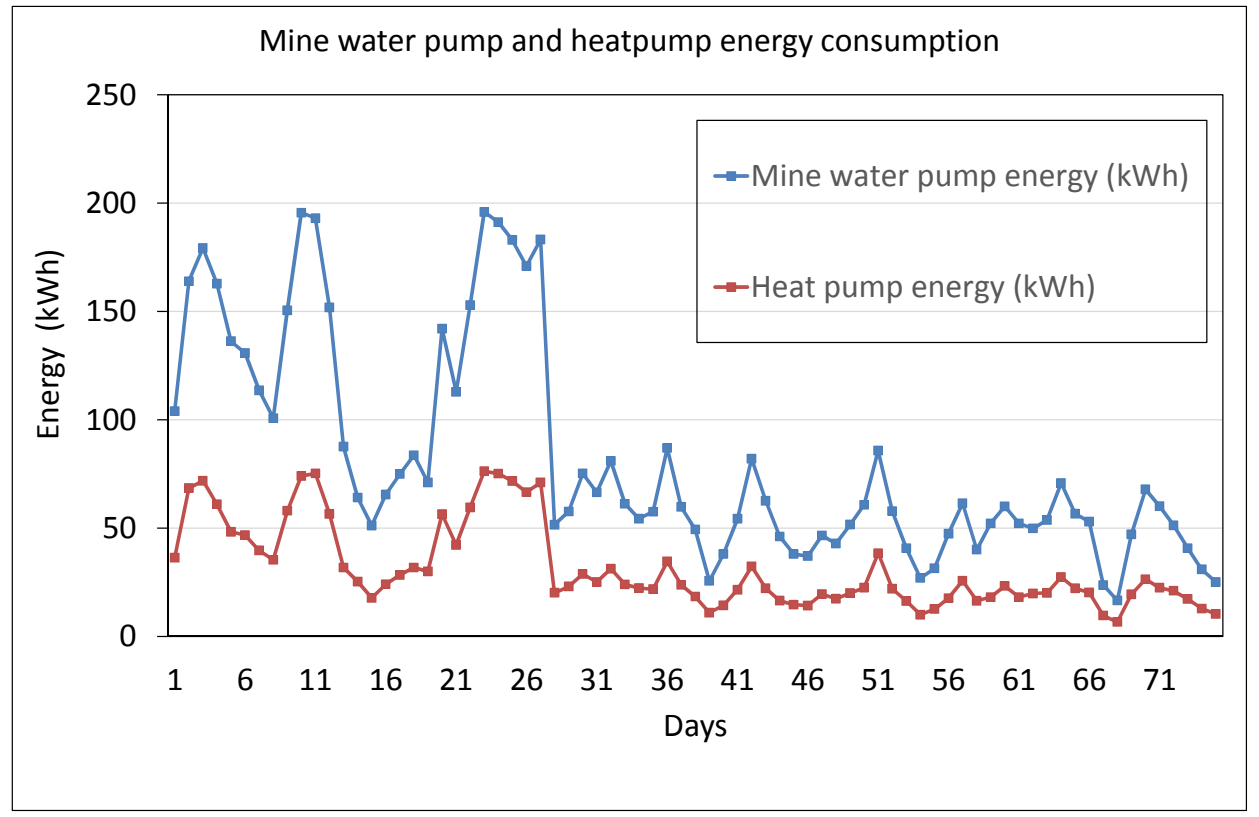

Figure 8: Daily energy usage by the heatpump and mine water pump.

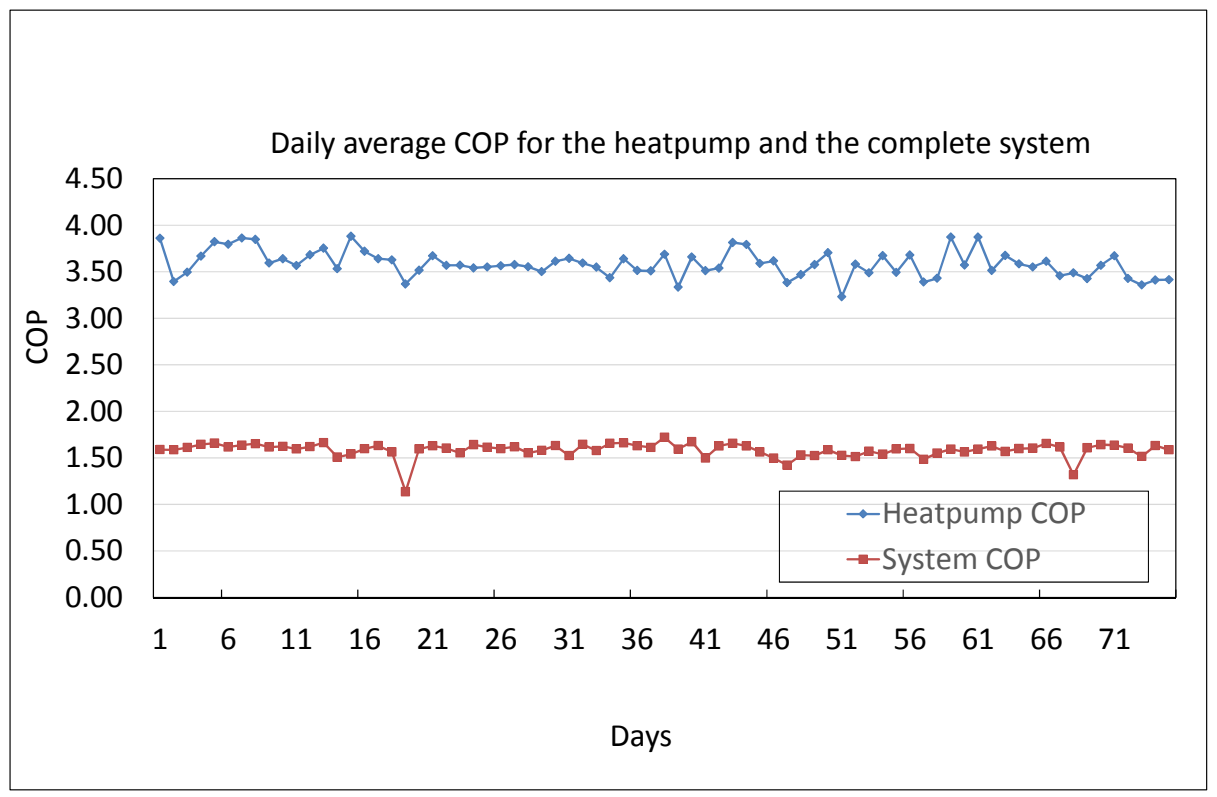

Figure 9: Daily average COP of heatpump and of the whole system. 


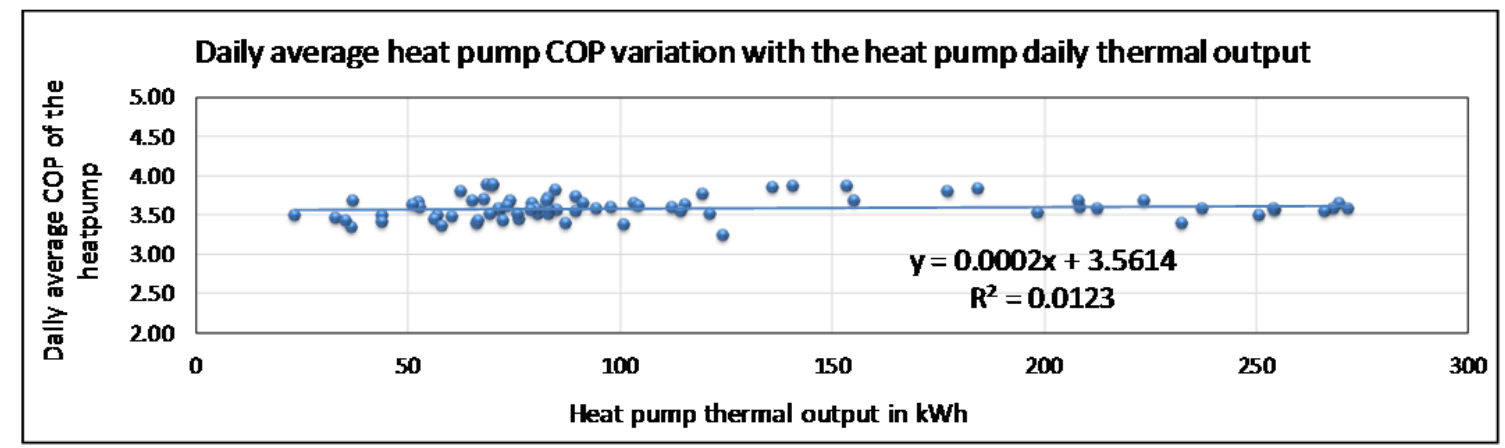

Figure 10: The relationship between heat pump COP and daily thermal output of the heat pump

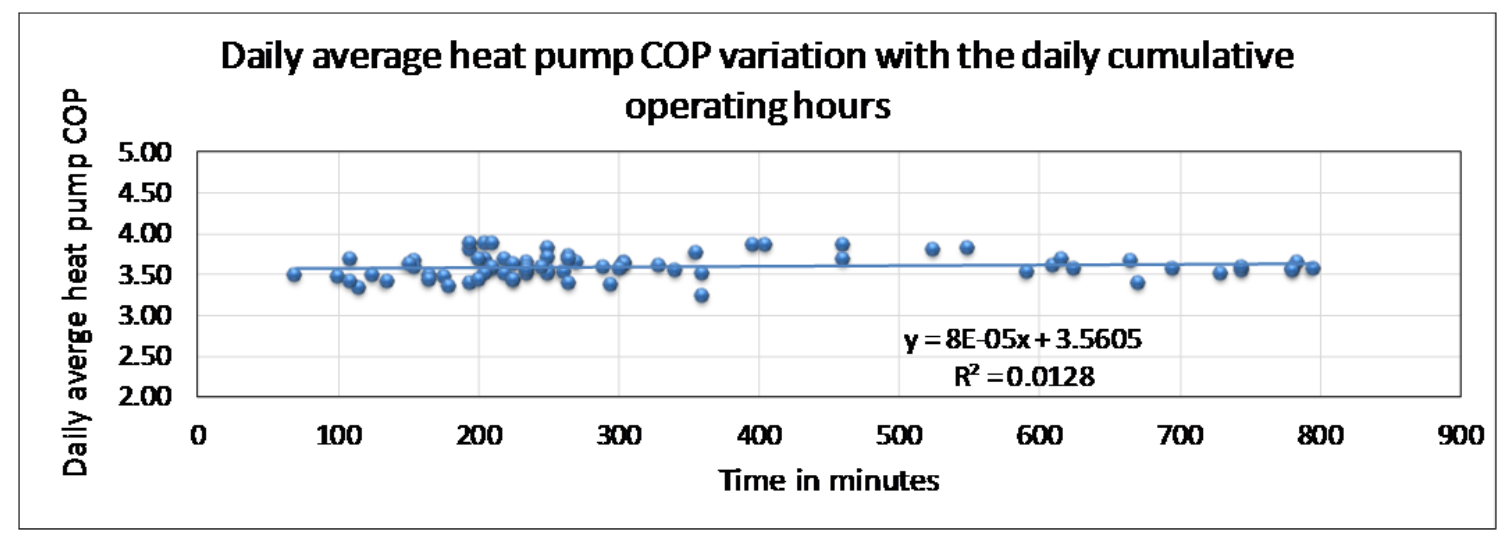

Figure 11: The heat pump COP variation for different operating hours.

Lower values of COP for the heat pump is attributed to the lower heat demand (running at sub optimal conditions) from the building, this results in cycling of the compressor of the heat pump. Figure 11 shows that there is some fluctuation in total number of hours the heat pump has operated each day, the longer the operating hours, the higher COP. As the heat pump runs for a longer duration in each cycle, the cycling (on/off) of the heat pump compressor is reduced. 


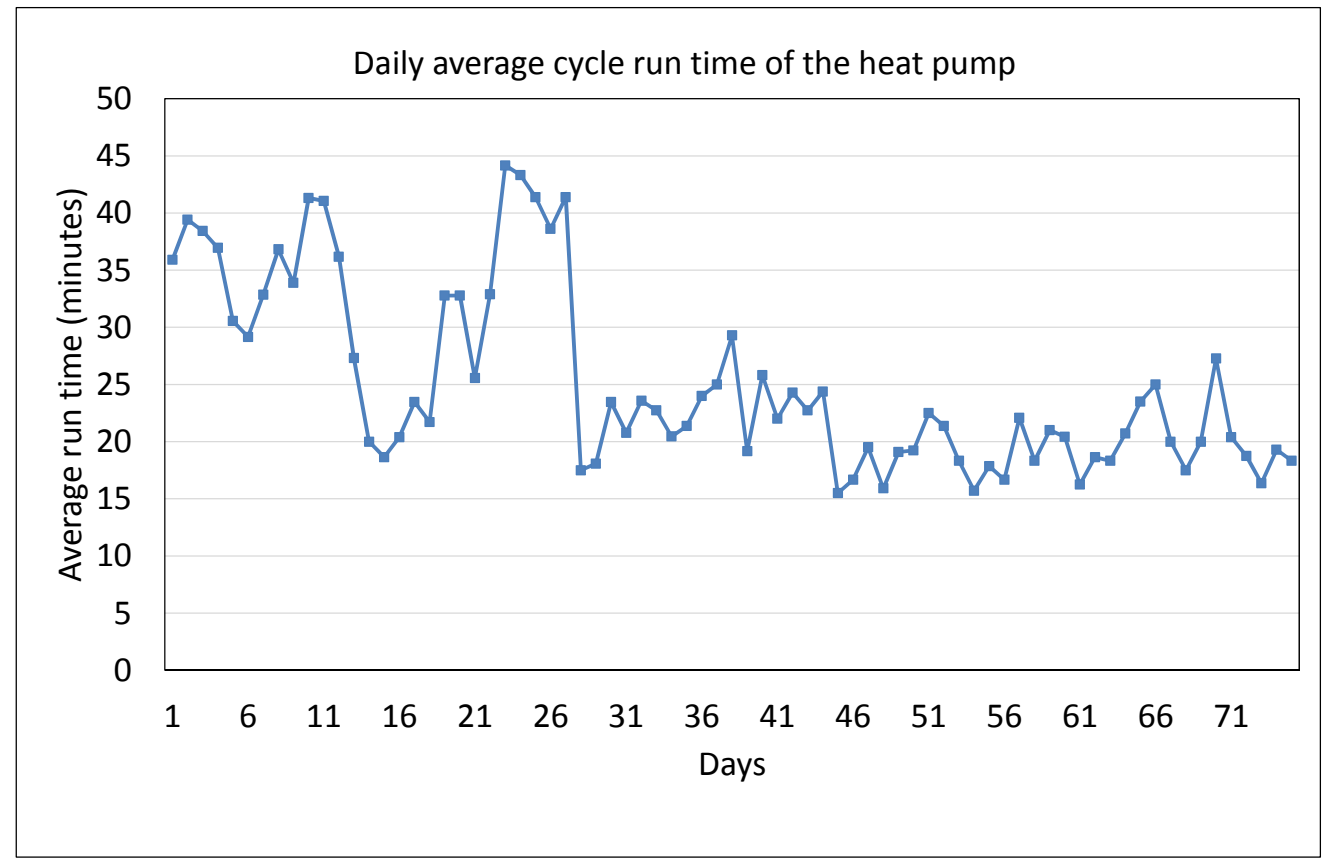

Figure 12: The daily average operational time (cycle time) in minutes of the heat pump.

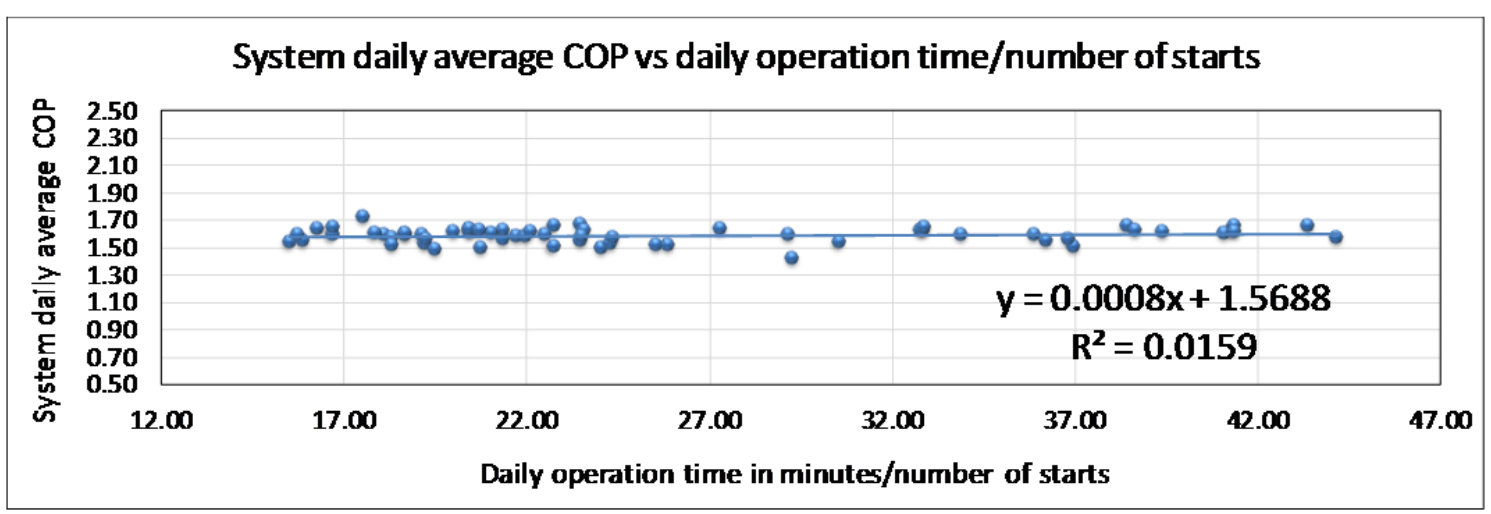

Figure 13: The relationship between the system's COP and the duration of each run (cycle time). 


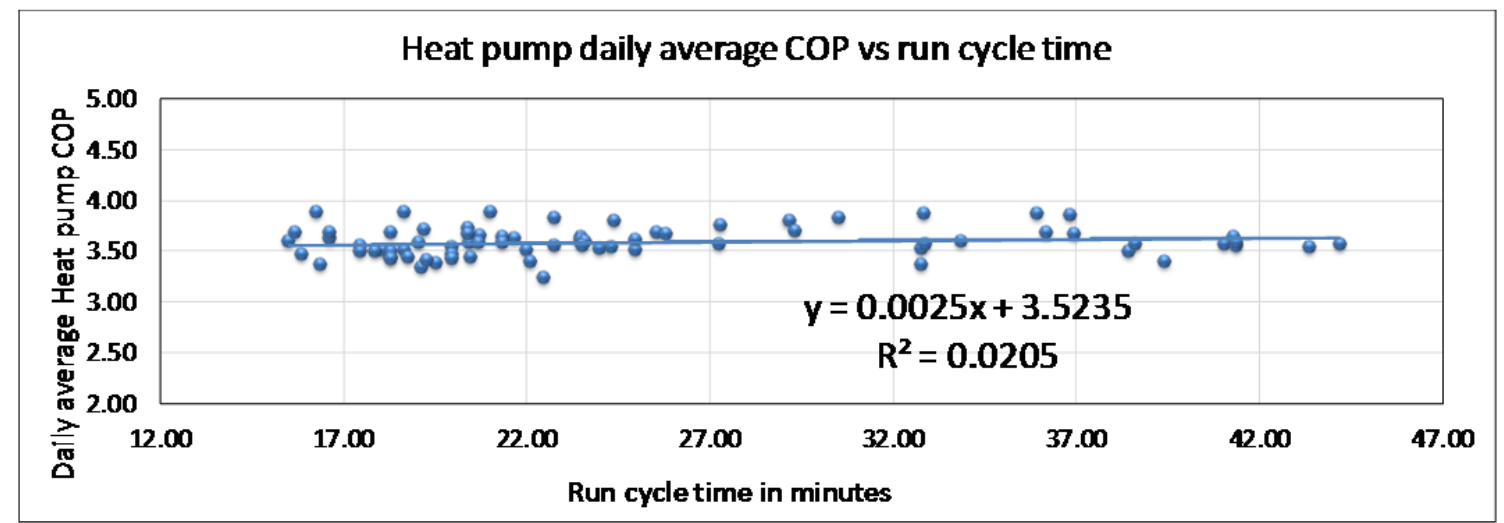

Figure 14: The relationship between heat pump's COP and duration of average run time (cycle time).

Figure 12 shows the variation in average operating cycle hours through the testing period. Figures 13 and 14, shows the variation in COP of the whole system and the heat pump, due to the fluctuation in the operating time of each cycle (time during which the compressor in continuous operation). The COP values tends to be slightly higher as the operating time of each cycle increases. Figure 15, shows further analysis indicating that when the operating cycle time in each run increases, the average COP increases and reaches the peak value of 3.72. When the average of a single run cycle time is between (22 to 27 minutes ) and the COP value reaches its maximum average. The range of average COP value at each run; i.e. the difference between the maximum and minimum values, at various run times shows that smaller range values occur at a longer duration of run time. Figure 15 indicates that there is an optimum run-time domain to deliver high COP with high stability (in this case 22 to 27 minutes ); any deviation from that will deliver lower COP and lower stability (i.e. a higher range). 


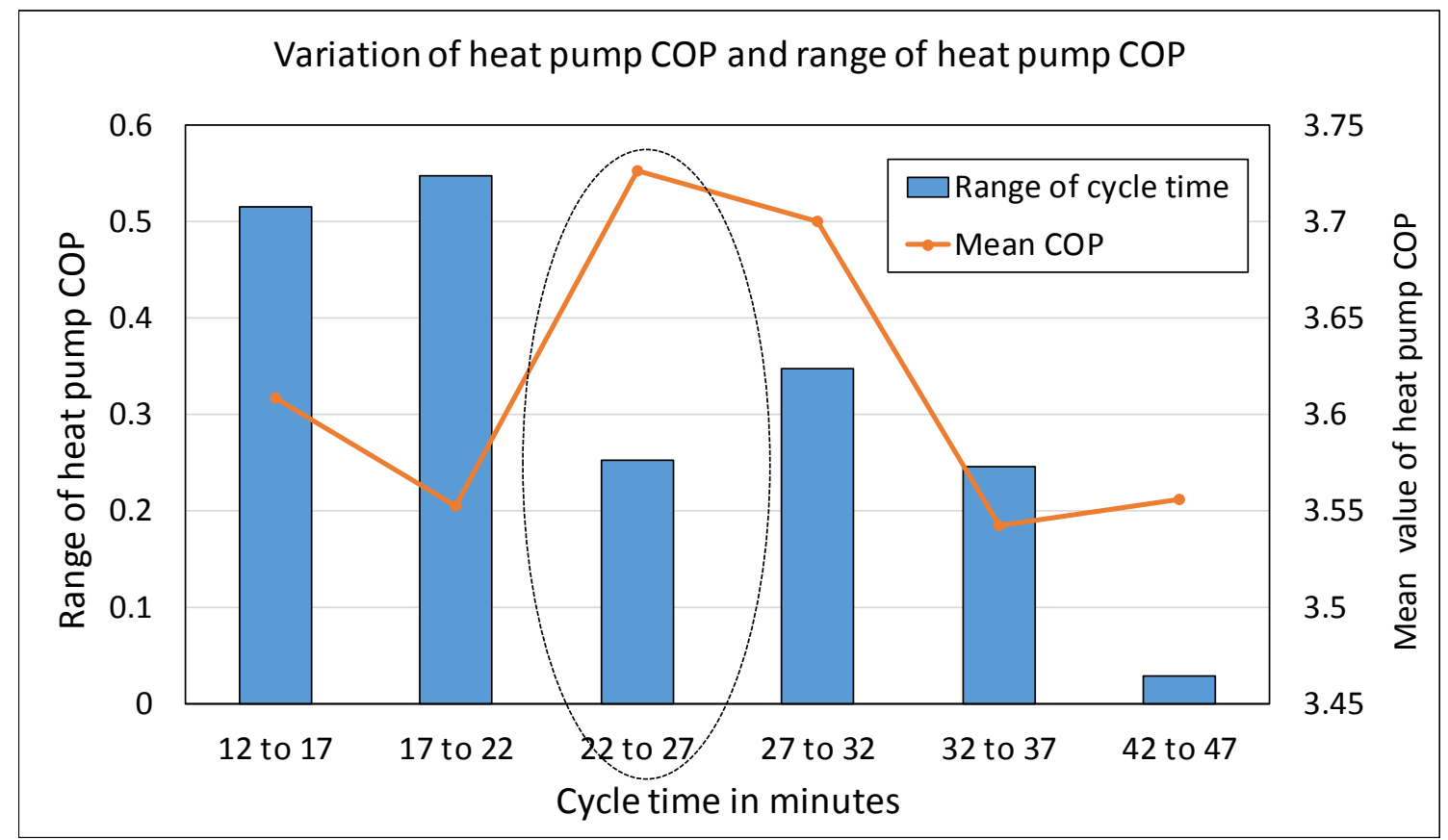

Figure 15: The variation of COP with run time of each cycle (duration of which the compressor of the heat pump in continuous operation).

The results show that temperature of the incoming mine water has remained stable during the operation. Figures 16 and Figure 17 indicate that there are no significant variation in the incoming mine water temperature over time, suggesting that the mine water energy is constantly replenished by either the geothermal rocks or the fresh inflow of warm water into the mine shaft from other coal seams. The mine water in the abandoned coal mines therefore represents a huge reservoir of low enthalpy water and is a reliable and secured source of energy which can be used profitably used for heating and cooling applications in a long run without any loss in its energy content.

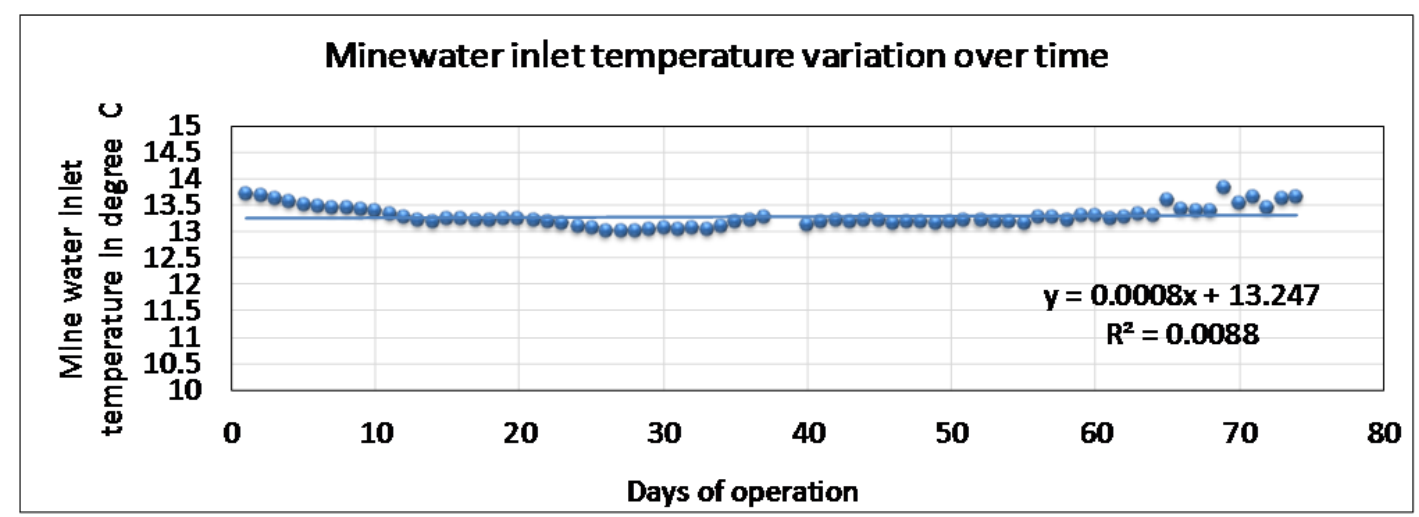


Figure 16: The daily average mine water inlet temperature values over time.

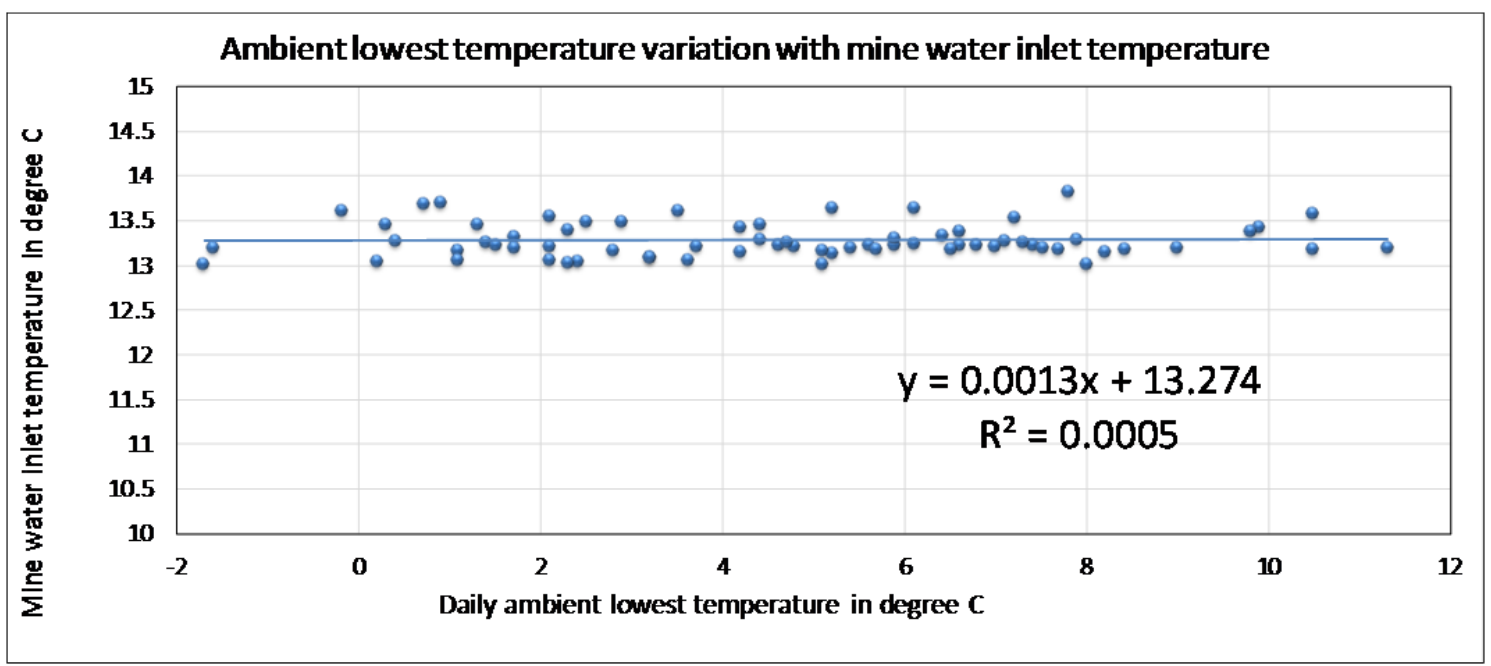

Figure 17: The mine water inlet temperature variation in relation to the lowest ambient temperature.

Figure 18 presents the relationship between the depth of water in Markham and its expected relationship with the COP values of heat pump and the COP of the whole system based on the obtained experimental results. At a depth of 100 metres, the overall COP value is about 2.7, when the COP of the heat pump is 4.8. This means for every $1 \mathrm{KWh}$ consumed by the system, $2.7 \mathrm{KWh}$ is produced as an output. The difference in energy is the energy extracted from the water of the mine. Due to the rising water level in the shaft, the overall COP is expected to reach a value of approximately 3.97 at a depth of 25 metres, with the heat pump COP reaching 4.8. Figure 19 presents the relationship between the flow rate of coal mine water and the COP of the system at different target output temperatures. It is evident that the increase in the flow rate will reduce the COP of the system for a given heating demand since no further energy will be extracted from the coal mine water, but increasing the mine pump power consumption. Also the increase in the target temperature will reduce the COP since the increase in temperature will increase the work needed by the heat pump to transfer the heat to a higher energy level. 


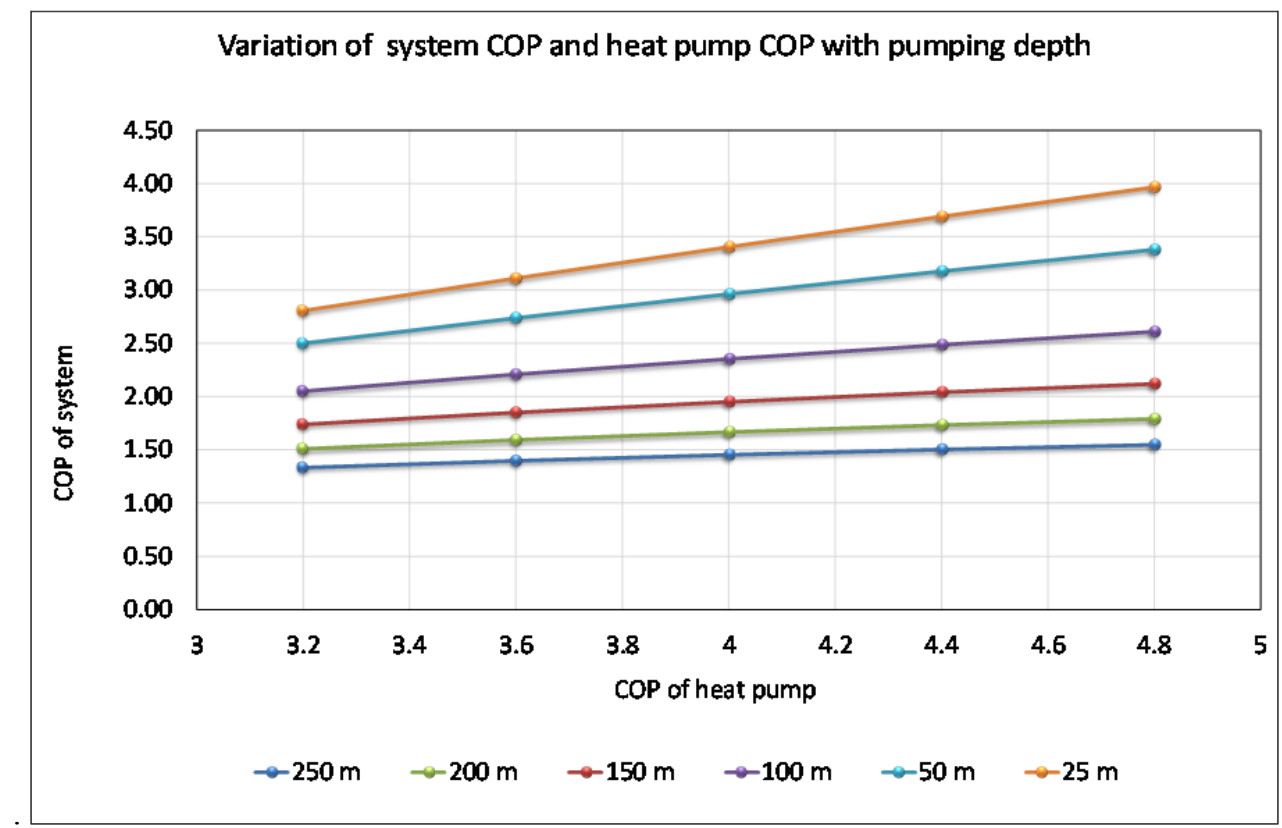

Figure 18: The relationship between the depth of water in the coal mine, COP of the heat pump and COP of the system

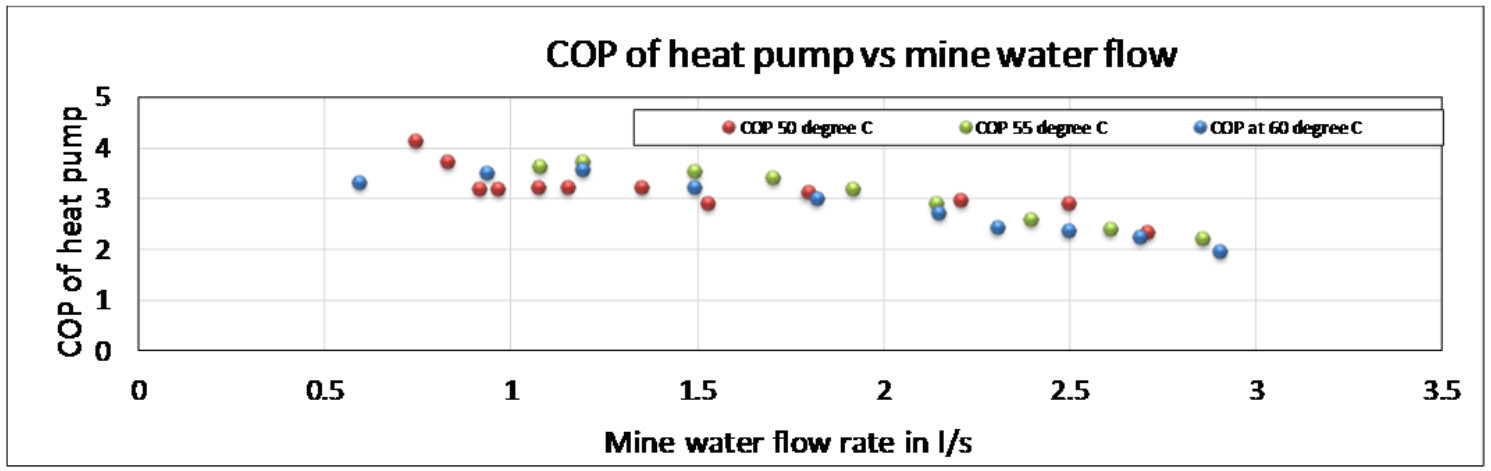

Figure 19: The relationship between mine water flow rate and COP of the system at different output

$$
\text { temperatures }
$$

\section{Conclusion}

This paper has presented a detailed analysis of using energy from flooded coal mines at Alkane Energy Markham site using a single shaft system. The analysis of the system's performance has indicated that the temperature of the mine water and the depth of water in the coal mine has a significant impact on the overall COP of the system, with the water level in the abandoned mines rising, the overall efficiency can only get better. The COP of the heat pump depends on the temperature of the incoming mine water, flow rate of mine water, heat demand from the building, ambient atmospheric temperature, optimum sizing of buffer tank and the hot water outlet temperature of the heat pump. The temperature of the mine water 
remains stable and does not vary over time from energy use or ambient temperature. Other benefits of using a single shaft open loop system is the reduced area needed on the site for the system, low capital investment costs as the need to have a second borehole to discharge water is eliminated. On the licensing and permitting side, since the mine water extracted is being injected back to its original source without altering its chemical properties, it is easier to get a consent from local authorities and also eliminates a potential problem of depleting the mine water level, which can have a major impact on the long term efficiency (COP) of the system. Water from flooded coal mines can be valuable source of low carbon energy especially in former brownfield mining regions which are can be regenerated into new industrial, commercial and housing developments which have substantial heating and cooling needs.

\section{Acknowledgments}

The authors would like to thank Alkane Energy Ltd for their support. This paper is based on field research carried out within the frame of research project: Low-Carbon After-Life (LoCAL) financed by the European Commission, Research Fund for Coal and Steel, July 2014 - June 2017 (Contract No.: RFCRCT-2014-00001).

\section{References}

[1] Younger, P.L., 2016. A simple, low-cost approach to predicting the hydrogeological consequences of coalfield closure as a basis for best practice in long-term management. International Journal of Coal Geology, 164, pp.25-34.

[2] Younger, P.L., Banwart, S.A. and Hedin, R.S., 2002. Chapter Three Mine Water Hydrology. Mine Water, pp.127-270.

[3] Bradley, K.F. and Ashford, K.T., Application of Geochemical Mineral Exploration Techniques to the Cataloguing of Problematic Discharges from Abandoned Mines in North-East England.

[4Coldewey, W.G. and Semrau, L., 1994, September. Mine water in the Ruhr area (Federal Republic of Germany). In Proceedings of 5th International Mine Water Congress, Leicestershire: Quorn Selective Repro Limited (Vol. 9, p. 148).

[5Dumpleton, S., 1996. The dangerous legacy of dead collieries. In International Journal of Rock Mechanics and Mining Sciences and Geomechanics Abstracts (Vol. 1, No. 33, p. 41A).

[6] Younger, P.L., 1998, July. Hydrological consequences of the abandonment of regional mine dewatering schemes in the UK. In Hydrology in a changing environment. Poster papers and index, int. symp. organised by the British Hydrological Society (pp. 6-10).

[7] Young, P.L., 1997. The longevity of minewater pollution: a basis for decision-making. Science of the Total Environment, 194, pp.457-466.

[8] Younger, P., 1993. Possible environmental impact of the closure of two collieries in County Durham. Water and Environment Journal, 7 (5), 521-531

[9] Younger, P., 1998. Coalfield abandonment: geochemical processes and hydrochemical products. Energy and the Environment.Geochemistry of Fossil, Nuclear and Renewable Resources. Society for Environmental Geochemistry and Health.MacGregor Science, Insch, , 1-29.

[10] Henton, M.P., 1981. The Problem of Water Table Rebound After Mining Activity and its Effect on Ground and Surface Water Quality. Studies in Environmental Science, 17, 111-116.

[11] Gzyl, G. and Banks, D., 2007. Verification of the "first flush" phenomenon in mine water from coal mines in the Upper Silesian Coal Basin, Poland. Journal of Contaminant Hydrology, 92 (1), 66-86.

[12] Wood, S., Younger, P. and Robins, N., 1999. Long-term changes in the quality of polluted minewater discharges from abandoned underground coal workings in Scotland. Quarterly Journal of Engineering Geology and Hydrogeology, 32 (1), 69-79.

[13 Stoertz, M.W., Hughes, M.L., Wanner, N.S. and Farley, M.E., 2001. Long-term water quality trends at a sealed, partially flooded underground mine. Environmental \& Engineering Geoscience, 7(1), pp.51-65. [14] Henton, M., 1979. Abandoned coalfields: problem of pollution. The Surveyor, 153 (9), e11.

[15 Banks, D., Younger, P.L., Arnesen, R.T., Iversen, E.R. and Banks, S.B., 1997. Mine-water chemistry: the good, the bad and the ugly. Environmental Geology, 32(3), pp.157-174. 
[16] Neymeyer, A., Williams, R. and Younger, P., 2007. Migration of polluted mine water in a public supply aquifer. Quarterly Journal of Engineering Geology and Hydrogeology, 40 (1), 75-84.

[17] Younger, P.L., 2008. Towards regulatory criteria for discharging iron-rich mine water into the sea. Mine Water and the Environment, 27 (1), 56-61.

[18] Bailey, M.T., Gandy, C.J., Watson, I.A., Wyatt, L.M. and Jarvis, A.P., 2016. Heat recovery potential of mine water treatment systems in Great Britain. International Journal of Coal Geology, 164, pp.7784.

[19] Rodríguez, R. and Díaz, M.B., 2009. Analysis of the utilization of mine galleries as geothermal heat exchangers by means a semi-empirical prediction method. Renewable Energy, 34 (7), 1716-1725.

[20] Watzlaf, G.R. and Ackman, T.E., 2006. Underground mine water for heating and cooling using geothermal heat pump systems. Mine Water and the Environment, 25 (1), 1-14.

[21] Hall, A., Scott, J.A. and Shang, H., 2011. Geothermal energy recovery from underground mines. Renewable and Sustainable Energy Reviews, 15 (2), 916-924

[22] Kindaichi, S., Nishina, D., Wen, L. and Kannaka, T., 2015. Potential for using water reservoirs as heat sources in heat pump systems. Applied Thermal Engineering, 76, pp.47-53.

[23] Raymond, J. and Therrien, R., 2008. Low-temperature geothermal potential of the flooded Gaspé Mines, Québec, Canada. Geothermics, 37 (2), 189-210.

[24] Ramos, E.P., Breede, K. and Falcone, G., 2015. Geothermal heat recovery from abandoned mines: a systematic review of projects implemented worldwide and a methodology for screening new projects. Environmental Earth Sciences, 73 (11), 6783-6795.

[25] Digges La Touche, G. and Preene, M., 2011. The potential use of ground energy in the mining industry-exploration to closure. In: Proceedings of the 11th International Mine Water Association Congress-Mine Water-Managing the Challenges, pp. 161-166.

[26 Ghoreishi Madiseh, S.A., Ghomshei, M.M., Hassani, F.P. and Abbasy, F., 2012. Sustainable heat extraction from abandoned mine tunnels: A numerical model. Journal of Renewable and Sustainable Energy, 4(3), p.033102.

[27 Banks, D., Skarphagen, H., Wiltshire, R. and Jessop, C., 2004. Heat pumps as a tool for energy recovery from mining wastes. Geological Society, London, Special Publications, 236(1), pp.499-513.

[28 Farr, G., Sadasivam, S., Watson, I.A., Thomas, H.R. and Tucker, D., 2016. Low enthalpy heat recovery potential from coal mine discharges in the South Wales Coalfield. International Journal of Coal Geology, 164, pp.92-103. [29] Omer, A.M., 2008. Ground-source heat pumps systems and applications. Renewable and Sustainable Energy Reviews, 12 (2), 344-371.

[30] Self, S.J., Reddy, B.V. and Rosen, M.A., 2013. Geothermal heat pump systems: Status review and comparison with other heating options. Applied Energy, 101, pp.341-348

[31] Chua, K.J., Chou, S.K. and Yang, W.M., 2010. Advances in heat pump systems: A review. Applied energy, 87(12), pp.3611-3624.

[32] Malolepszy, Z., Demollin-Schneiders, E. and Bowers, D., 2005, April. Potential use of geothermal mine waters in Europe. In Proceedings of the World Geothermal Congress (pp. 1-3).

[33] Banks, D., Skarphagen, H., Wiltshire, R. and Jessop, C., 2003. Mine water as a resource: space heating and cooling via use of heat pumps. Land Contamination \& Reclamation, 11(2), pp.191-198.

[34] Raymond, J. and Therrien, R., 2008. Low-temperature geothermal potential of the flooded Gaspé Mines, Québec, Canada. Geothermics, 37 (2), 189-210.

[35] Al-Habaibeh, A., Meyerowitz, B. and Athresh, A., 2015. The design and development of an innovative simulator for an open loop system for extracting energy from flooded coal mines. Energy Procedia, 75, pp.1470-1476.

[36] Nguyen, H.V., Law, Y.L.E., Alavy, M., Walsh, P.R., Leong, W.H. and Dworkin, S.B., 2014. An analysis of the factors affecting hybrid ground-source heat pump installation potential in North America. Applied Energy, 125, pp.28-38.

[37] Jessop, A.M., MacDonald, J.K. and Spence, H., 1995. Clean energy from abandoned mines at Springhill, Nova Scotia. Energy Sources, 17 (1), 93-106

[38 Jardón, S., Ordóñez, A., Alvarez, R., Cienfuegos, P. and Loredo, J., 2013. Mine water for energy and water supply in the Central Coal Basin of Asturias (Spain). Mine water and the environment, 32(2), pp.139-151.

[39] Preene, M. and Younger, P.L., 2014. Can you take the heat?-Geothermal energy in mining. Mining Technology, 123(2), pp.107-118. 
[40] Banks, D., Pumar, A.F. and Watson, I., 2009. The operational performance of Scottish minewaterbased ground source heat pump systems. Quarterly Journal of Engineering Geology and Hydrogeology, 42(3), pp.347-357.

[41] Gillespie, M.R., Crane, E.J. and Barron, H.F., 2013. Deep geothermal energy potential in Scotland. British Geological Survey Commissioned Report, CR/12/131.

[42] Coal Authority UK, 2016. Coal Authority UK [online]. . Available at: https://www.gov.uk/government/organisations/the-coal-authority [Accessed 05/05 2016].

[43] Parker, K., 2011. Potential for heat pumps in Yorkshire and the rest of the United Kingdom. Heat pump technology using minewater,(ed. Faull ML), pp.32-42.

[44] Burnside, N.M., Banks, D., Boyce, A.J. and Athresh, A., 2016. Hydrochemistry and stable isotopes as tools for understanding the sustainability of minewater geothermal energy production from a 'standing column'heat pump system: Markham Colliery, Bolsover, Derbyshire, UK. International Journal of Coal Geology, 165, pp.223-230.

[45] Athresh, A.P., Al-Habaibeh, A. and Parker, K., 2016. The design and evaluation of an open loop ground source heat pump operating in an ochre-rich coal mine water environment. International Journal of Coal Geology, 164, pp.69-76.

[46] Roijen, E., Op`t Veld, P. and Demollin-Schneiders, E., 2007. The Minewaterproject Heerlen-low exergy heating and cooling in practice. PALENC AIVC.

[47] Verhoeven, R., Willems, E., Harcouët-Menou, V., De Boever, E., Hiddes, L., Op't Veld, P. and Demollin, E., 2014. Minewater 2.0 project in Heerlen the Netherlands: transformation of a geothermal mine water pilot project into a full scale hybrid sustainable energy infrastructure for heating and cooling. Energy Procedia, 46, pp.58-67.

[48] Esen, H., Esen M. and Onur Ozsolak, Modelling and experimental performance analysis of solarassisted ground source heat pump system, Journal of Experimental \& Theoretical Artificial Intelligence, 29(1), 1-17 (2017).

[49] Esen, M. and Balbay A. , Experimental investigation of using ground source heat pump system for snow melting on pavements and bridge decks, Scientific Research and Essays, 5 (24) (2010) 39553966.

[50] Balbay, A. and Esen, M., Temperature distributions in pavement and bridge slabs heated by using vertical ground-source heat pump systems, Acta Scientiarum-Technology, 35(4), 677-685 (2013).

[51] Esen, M. and Yuksel, T., Experimental evaluation of using various renewable energy sources for heating a greenhouse, Energy and Buildings, 65, 340-351 (2013).

[52] Athresh, A.P., Al-Habaibeh, A. and Parker, K., 2015. Innovative approach for heating of buildings using water from a flooded coal mine through an open loop based single shaft GSHP system. Energy Procedia, 75, pp.1221-1228.

[53] Banks, D., Athresh, A., Al-Habaibeh, A. and Burnside, N., 2017. Water from abandoned mines as a heat source: practical experiences of open-and closed-loop strategies, United Kingdom. Sustainable Water Resources Management, pp.1-22.

[54] Athresh, A.P., Al-Habaibeh, A. and Parker, K., 2017. An innovative and integrated approach for using energy from the flooded coal mines for pre-warming of a gas engine in standby mode using GSHP. Energy Procedia, 105, pp.2531-2538.

[55] Ochsner, K., 2012. Geothermal Heat pumps: a Guide for planning and Installing. Routledge.

[56] Bazargan Sabet, D., Demollin, E. and Van Bergermeer, J., 2008. Geothermal use of deep flooded mines. In: Proceedings of Post-Mining Symposium, Nancy, France. 